\title{
Control of Rice Weevil, Sitophilus oryzae (L.), in Stored Wheat Grains with Mesquite Plant, Prosopis juliflora (SW), D.C. Seed Extracts
}

\author{
N.H. Al-Moajel \\ Girls College, Saudi Arabia, P.O. BOX 58202, Riyadh 11594 \\ مكافحة حشرة سوسة الأرز في القمح المخزن باستخدام مستخلصات بذور
}

نادرة المعجل

خلاصةة: تم تقبيم فعالية مستخلصات بذور نبات العاف على سوسة الإز المرياة على حبوب القمح. كان للمستخلصات

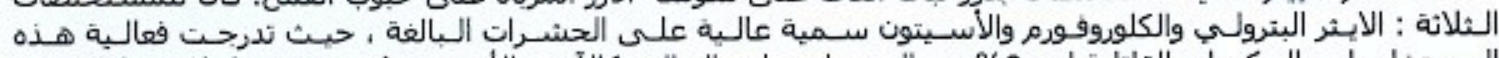

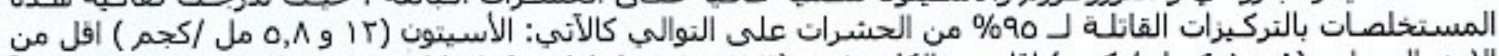

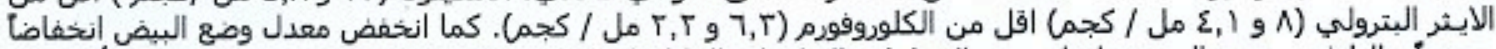

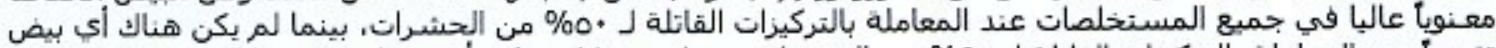

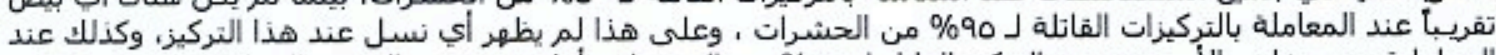

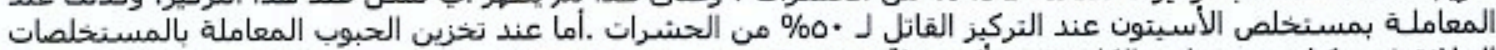

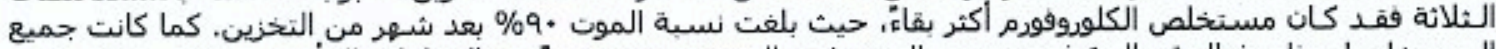

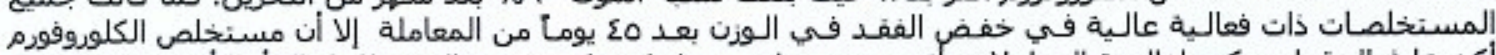

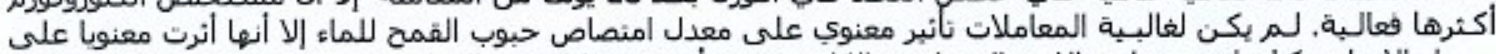

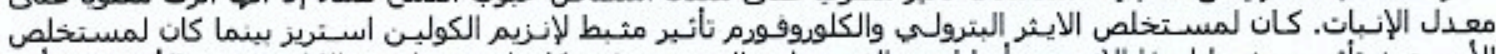

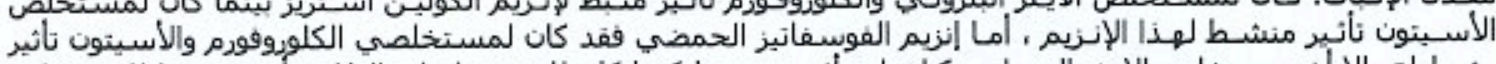

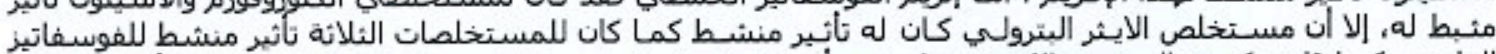

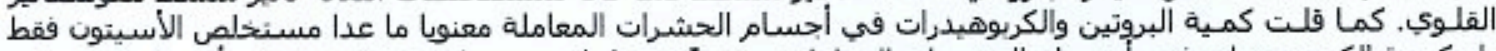

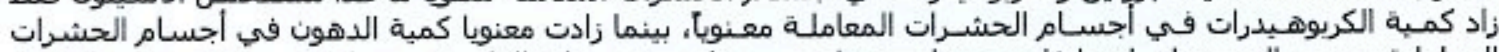

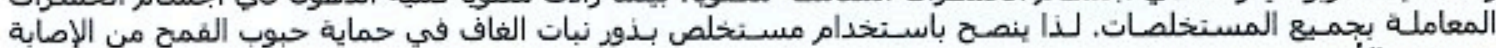

بسوسـة الأبرز.

ABSTRACT: The effectiveness of mesquite plant, Prosopis juliflora (S.W) D.C. (Family: Mimosaceac), seed extracts against rice weevil, Sitophilus oryzae (L.), reared on wheat grains was investigated in the laboratory. The tested plant extracts of $P$. juliffora in petroleum ether, chloroform, and acetone, effectively controlled adults and their toxicity based on $L C_{95}$ and $L_{50}$ values respectively was in order: acetone $(12.0,5.8 \mathrm{ml} / \mathrm{kg})<$ pet ether $(8.0,4.1 \mathrm{ml} / \mathrm{kg})<$ chloroform $(6.3,2.2 \mathrm{ml} / \mathrm{kg})$. A highly significant oviposition deterency effect $(\mathrm{P}<0.05)$ was found for all extracts at $\mathrm{LC}_{50}$ levels, while at $\mathrm{LC}_{95}$ levels, oviposition was nearly completely inhibited. Thus, progeny emergence was completely suppressed at $\mathrm{LC}_{95}$ levels, also at $\mathrm{LC}_{50}$ of acetone extract. Chloroform extract indicated a slow rate of degradation after one month of storage ( $90 \%$ mortality). All tested plant extracts reduced weight loss in wheat grains after 45 days of storage, but chloroform extract was the most effective. Most treatments did not significantly affect water absorption but viability was significantly reduced. Petroleum ether and chloroform extracts caused a significant inhibition effect on acetyl choline esterase (AchE) in adults while acetone extract caused a significant activation effect. All three different extracts, caused a significant activation effect on phosphases (AcP and AlkP), except for chloroform and acetone extract treatments which caused significant inhibition of AcP in adults. All extracts caused a significant decrease in protein and carbohydrate contents of adults, except the carbohydrate content of adults treated with acetone extract. There was a significant increase in lipid content in adults treated with all three extracts and significant increase of carbohydrate content only in adults treated with acetone extract.

Keywords: Grain protectants, Sitophilus oryzae, acetylcholinesterase, phosphatase, metabolites. 
$\mathrm{C}$ urrently the measures to control pest infestation in stored grain products rely heavily upon the use of conventional insecticides which can lead to problems of toxic residues and environmental contamination (Zettler and Cuperus, 1990; White, 1995).

Indigenous materials of botanical origin are an important source of grain protectants, because they have been found to exhibit toxic effects against insects (Arroyo, 1995). Research on the evaluation of available local plant protection is necessary to help farmers to use these plants, grown locally, to limit post-harvest losses of their products to different insects.

The mesquite plant, Prosopis juliflora, is common and widely spread in most parts of Saudi Arabia (Collenette, 1998, 1999; Chaudhary and Al-Jowaid, 1999). The aqueous extracts of the leaves were previously considered to have antibacterial (Satish et al., 1999) and antifungal (Ahmed et al., 1997; Kurucheve et al., 1997; Gomathi and Kannabiran, 2000 ) properties. The efficacy of $P$. juliflora leaf extracts was reported against Callosobruchus analis (Tabassum et al., 1994) and Plutella xylostella (Torres et al., 2001). The efficacy of the plant powder and seed extracts against $C$. maculatus were studied by AlMoajel and Al-Dosary $(2002,2003)$. Further studies are needed to know the effectiveness of $P$. juliflora on other insect pests. Keeping this in view, our present experiment was undertaken to evaluate the effectiveness of $P$. juliflora seed extracts as a protectant against the rice weevil, by testing effects on adult mortality, egg laying, adult emergence, grain weight loss, residual effects, grain viability, grain water absorption, enzymes and main metabolites of $S$. oryzae adults.

\section{Materials and Methods}

REARING TECHNIQUE: $S$. oryzae were cultured in glass jars containing with wheat grains under controlled temperature and relative humidity $\left(27^{\circ} \mathrm{C}\right.$ and $70 \%$ R.H.). The new cultures were prepared by adding $200-$ 300 adults (unsexed) from a stock culture to about $500 \mathrm{~g}$ of wheat grain in a glass jar. After 3 weeks of the oviposition period, the parent adults were removed, and one week old insects subsequently emerging were used for the experiments. All experiments were conducted under the same condition using wheat grains.

EXTRACTION TECHNIQUE: Mesquite seeds obtained from the local market were washed, dried and ground in an electric grinding machine. A sufficient quantity of powder was extracted with organic solvents (of increasing polarity), petroleum ether, chloroform and acetone as described by Su (1985). The solvents were sequentially used to extract the active ingredients for a period of $48 \mathrm{~h}$ each at room temperature, then filtered through anhydrous sodium sulfate. A rotary evaporator was used to remove the solvents. The oils obtained in each case were stored in labeled plastic cap bottles at $5^{\circ} \mathrm{C}$ until required for use (Islam, 1983). The diagrammatic presentation of the whole extraction process is given in Figure 1.

MIXING TECHNIQUE: For all experiments, extracts were added to wheat grains in glass jars using three solvents as a carrier, shaken thoroughly and then solvent was allowed to evaporate in a stream of air.

All treatments were replicated at least three times. In all cases, the experiments were performed in incubators at constant temperature $27^{\circ} \mathrm{C}$ and $70 \%$ R.H. The grains in the control treatments were treated with $0.2 \mathrm{ml}$ of each solvent. All treated jars were covered with pieces of cloth, fastened with rubber bands to prevent contamination and the escape of insects.

ADULT MORTALITY: Four different concentrations were prepared from each extract after preliminary tests. Twenty unsexed adults of $S$. oryaze, were introduced into each jar containing $10 \mathrm{~g}$ of wheat grains. The effects of $P$. juliflora seed extracts on the survival of adults were assessed by recording mortality at $1,3,5,7$ and 14 days after release. Adults were considered as dead when no response was obtained after probing the abdomen with forceps.

Insect mortality was calculated for each concentration using the formula proposed by Abbott (1987). $\mathrm{LC}_{50}$ and $\mathrm{LC}_{95}$ values during the first three days were calculated by probit analysis (SPSS, 1999). The data were subjected to analysis of variance (ANOVA). Significant differences between treatment means were separated at the $\mathrm{P}=0.05$ by Duncan's (1951) Multiple Range Test. Standard errors of means were computed.

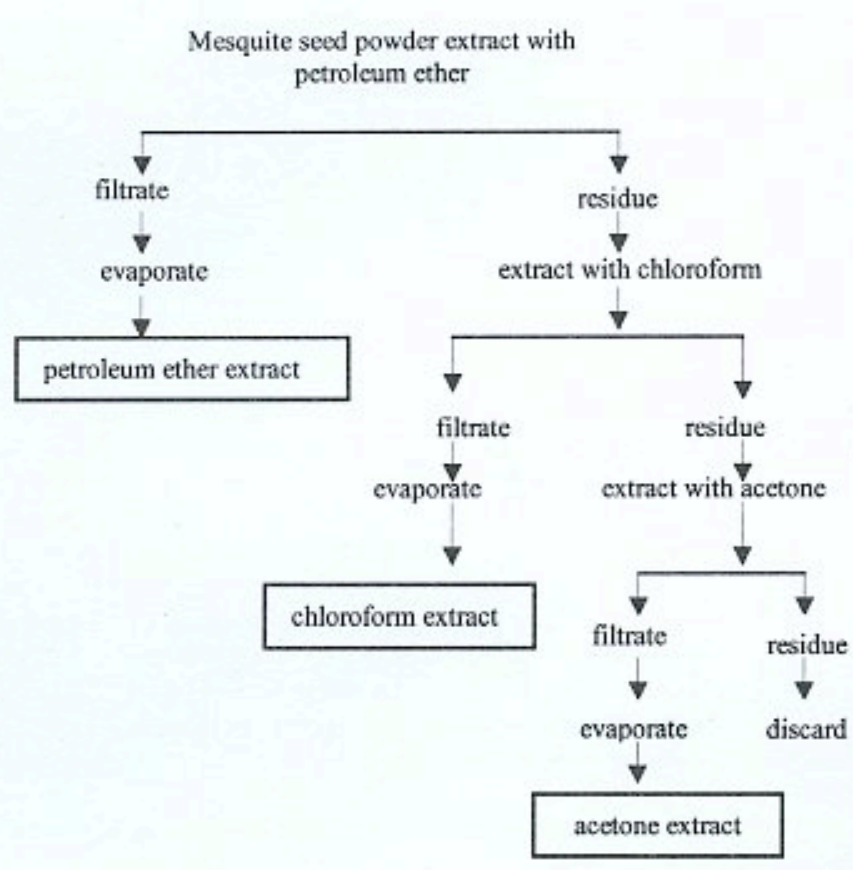

Figure 1. Schematic presentation of mesquite seed extraction. 


\section{CONTROL OF RICE WEEVIL, S. ORYZAE (L.), IN STORED WHEAT GRAINS WITH \\ MESQUITE PLANT, P. JULIFLORA (SW), D.C. SEED EXTRACTS}

OVIPOSITION AND ADULT EMERGENCE: Concentrations corresponding to $\mathrm{LC}_{50}, \mathrm{LC}_{95}$ and controls of either petether, chloroform and acetone extracts were applied to each of three replicates consisting of $5 \mathrm{~g}$ wheat grains in a glass jar. Ten pairs (1-7 day old) of $S$. oryzae adults were added to each jar. They were sexed following the method described by Halstead (1963). Each jar was covered with a muslin cloth held in place with rubber bands. Observations on egg laying capacity of weevils in each treatment were taken after 10 days.

Acid fucshin stain was employed for the detection of the eggs (Frankenfeld, 1950). The eggs were counted from the stained grain samples. Similar treatments were made to determine total emergence.

After 10 days, the insects were removed, and adults of first generation were removed daily and counted. The following formula was used to determine the percentage reduction in the number of eggs and offspring

$$
\%=\frac{\mathrm{X}}{\mathrm{Y}} \times 100
$$

where $\mathrm{X}$ is the number of eggs or adults in the treatment and $\mathrm{Y}$ is the number of eggs or adults in the control. Standard errors of the means were computed. For comparisons between treatment and control, t-test was used.

GRAIN WEIGHT Loss: Percent loss in grain weight was calculated following Khare and Johari (1984). The data were analyzed statistically by using t-test at the $5 \%$ significant level. Standard error of means was calculated.

RESIDUAL EFFECT: To assess the persistence of the treatments, each test extract - $\mathrm{LC}_{95}$ concentrations including control - was mixed with $1 \mathrm{~kg}$ samples of wheat grains and stirred continuously for $30 \mathrm{~min}$ to ensure even spread of the material over the surface of the grains. Treated grains and controls were allowed to dry for 2 hours before storage.

The grains of each treatment were infested every three days with adult weevils of mixed sex. For each 10 g sample, 20 adults of $S$. oryzae were introduced in each replicate (three replicates from each concentration and the control). Mortality counts were recorded after 3 days, and the data were analyzed to calculate $\mathrm{LT}_{50}$ and $\mathrm{LT}_{95}$ values.

GRAIN VIABILITY AND WATER ABSORPTION: Viability and water absorption tests of the treated wheat grains were conducted 1 and 30 days after treatment. From each treatment 30 grains with $\mathrm{LC}_{95}$ concentrations of all extracts (initial and after storage periods and controls) were kept in three Petri dishes (3 replicates) on two layers of moistened Whatman filter paper. Treatments were moistened daily. Germination was recorded after 10 days (Anonymous, 1966).

Water absorption tests were carried out in small jars three quarters full of distilled water. Two grams of treated grains and controls were submerged in water for 1, 5 and $24 \mathrm{hr}$ (Tikka et al., 1981; Qi and Burkholder, 1981; and Sighamony et al., 1986). At the end of each period, the grains were dried with filter paper and reweighed to estimate the water absorbed.

Means were recorded and reduction in germination and water absorption were determined. Results were analyzed by ANOVA, and means were compared using Duncan's Multiple Range Test.

\section{ENZYMES ASSAY:}

\section{Esterases}

Acetylcholine esterase (AchE) - Acetylcholine esterase (AchE) was measured according to the method described by Simpson et al. (1964).

\section{Phosphatases}

Phosohatases enzymes (AcP and AlkP) - Acid phosphatase (AcP) and alkaline phosphatase (AlkP) were determined according to the method described by Powell and Smith (1954).

\section{Main metabolites}

Total proteins: - Total proteins were determined by the method of Bradford (1976).

Total carbohydrates: - Total carbohydrates were determined by the method described by Singh and Sinha (1977).

Total lipids: -_Total lipids were estimated according to Knight et al. (1972).

Results were analyzed using t-test at 5\% significant level.

\section{Results and Discussion}

EFFECT ON AdUlT Mortality: The data in Table 1 show that $P$. juliflora seed extracts were remarkably effective causing mortality after 3 days at almost all concentrations of $S$. oryzae, However, within 1 day of exposure to wheat grains treated with pet-ether and chloroform extracts, 20 and $25 \%$ of the weevil adults respectively were killed at $5 \mathrm{ml} / \mathrm{kg}$.

After 5 days of exposure, one hundred percent mortality was achieved by pet-ether, chloroform and acetone extracts at 5,3 and 10 concentrations, respectively. A similar trend in mortality was observed with most other extracts after 7 days of exposure.

The effects of higher and lower concentrations of extracts on adult mortality was almost significantly different from each other. Mortality was directly proportional to the concentration level and to time. When each treatment was compared with the control, a significant difference was obtained $(\mathrm{P}<0.05)$. 
TABLE 1

Average mortality of $\mathrm{S}$, oryzae adults when exposed to wheat grain treated with different concentrations of $\mathrm{P}$. juliflora seed extracts.

\begin{tabular}{|c|c|c|c|c|c|c|}
\hline \multirow{3}{*}{ Extract } & \multirow{3}{*}{$\begin{array}{c}\text { Concen- } \\
\text { tration } \\
(\mathrm{m} / \mathrm{kg})\end{array}$} & \multicolumn{5}{|c|}{$\%$ Cumulative mortality ${ }^{*}$} \\
\hline & & \multicolumn{5}{|c|}{ Day5 } \\
\hline & & 1 & 3 & 5 & 7 & 14 \\
\hline \multirow[t]{4}{*}{ Pet-ether } & 3 & $0^{\text {sate }}$ & $30^{\text {atch }}$ & $71^{\text {ab }}$ & $73^{*}$ & $79^{a}$ \\
\hline & 4 & $2^{\text {ale }}$ & $40^{3 t i}$ & $82^{\text {ste }}$ & 85 & $100^{\circ}$ \\
\hline & 5 & $20^{\text {hoody }}$ & $60^{\text {czij }}$ & $100^{\circ e}$ & - & - \\
\hline & 6 & $29^{\mathrm{kx}=\mathrm{fg}}$ & $85^{\mathrm{dfg}_{\mathrm{g}}}$ & $100^{\mathrm{ce}}$ & - & - \\
\hline Control & & 0 & 0 & 0 & 0 & 4 \\
\hline \multirow[t]{4}{*}{ Chloroform } & 1 & $0^{\text {ale }}$ & $20^{\text {th }}$ & $54^{d}$ & $70^{\text {kd }}$ & $74^{s}$ \\
\hline & 2 & $0^{\text {asc }}$ & $30^{\text {thath }}$ & $81^{\text {ste }}$ & $100^{\text {te }}$ & - \\
\hline & 3 & $8^{\text {stdef }}$ & $57^{a j i}$ & $100^{\epsilon e}$ & - & - \\
\hline & 5 & $25^{\mathrm{bx} f \mathrm{f} g}$ & $95^{4}$ & $100^{\circ e}$ & - & - \\
\hline Control & & 0 & 0 & 2 & 2 & 4 \\
\hline \multirow[t]{4}{*}{ Acetone } & 4 & $0^{a c}$ & $20^{\text {scth }}$ & $52^{d}$ & $62^{\text {od }}$ & $73^{3}$ \\
\hline & 6 & $4^{\text {ate }}$ & $46^{\mathrm{bcp}}$ & $90^{\text {toe }}$ & $100^{\text {bde }}$ & - \\
\hline & 8 & $16^{\text {bad }}$ & $63^{c 2}$ & $94^{\text {bec }}$ & $100^{\text {bec }}$ & - \\
\hline & 10 & $32^{\mathrm{bxg}}$ & $95^{\mathrm{df}}$ & $100^{c e}$ & - & - \\
\hline Control & & 0 & 0 & 0 & 4 & 8 \\
\hline F-ratio & & 7.82 & 30.42 & 17.13 & 18.04 & 16.93 \\
\hline F-tabulated & & & & .216 & & \\
\hline LSD & & 21.51 & 8.25 & 15.19 & 15.00 & 18.36 \\
\hline
\end{tabular}

*Each datum point is a mean of three replicates and was corrected for mortalities in the control (Abbott's formula).

- Mortality means in each column differ significantly at the significance level indicated for each column (ANOVA).

- Means in the same column with the same letters are not significantly different (Duncan's Multiple Range Test $\mathrm{P}<0.05$ ).

directly proportional to the level concentration and to time. When each treatment was compared with the control, a high significant difference was obtained ( $\mathrm{P}<$ 0.05 ).

The slopes of the probit lines were steeper as concentration increased (Table 2). On the basis of relative toxicity at both levels $\left(\mathrm{LC}_{50}\right.$ and $\left.\mathrm{LC}_{95}\right)$, the treatment may be summarized as: chloroform extract $(2.2,6.3 \mathrm{ml} / \mathrm{kg})>$ pet-ether extract $(4.1,8.0 \mathrm{ml} / \mathrm{kg})>$ acetone extract $(5.8,12.0)$ at $\mathrm{LC}_{50}$ and $\mathrm{LC}_{95}$ values respectively. The data on adult mortality showed a strong relationship between mortalities and extract concentrations and more than $50 \%$ of adult mortality occurred at all tested concentrations of all extracts after an exposure period of 5 days. Hence, the ANOVA showed statistically significant differences. Consequently, the tested concentrations of the plant extracts are sufficient to cause significant mortalities. This was reported by Naqvi and Parveen, (1991), Tabassum et al. (1994) and AlMoajel, (2003).

Recently, many researchers have worked on the pesticidal properties of plant extract essential oils against $S$. oryzae (Risha et al., 1990; Chander et al., 1991; Shaaya et al., 1991, 1997; Niber et al., 1992; Chimbe and Galley, 1996; El-Lakwah et al., 1998; Kestenholz and Stevenson, 1998; Owusu, 2001). In respect of $P$. juliflora plants, only three studies have been carried out on the toxicity of leaf extracts or juliflorine on stored-product insect species. Juliflorine was found to be the principal bioactive compound in leaves for use
TABLE 2

Toxicity of $\mathrm{P}$. juliflora seed extracts applied to wheat grains against adults of $\mathrm{S}$. oryzae.

\begin{tabular}{lccc}
\hline Extract & Slope & $\mathrm{LC}_{50}(\mathrm{ml} / \mathrm{kg})$ & $\mathrm{LC}_{95}(\mathrm{ml} / \mathrm{kg})$ \\
\hline Pet-ether & 5.70 & 4.1 & 8.0 \\
Chloroform & 3.52 & 2.2 & 6.3 \\
Acetone & 5.20 & 5.8 & 12.0 \\
\hline
\end{tabular}

against Musca domestica larvae (Jahan et al., 1990) and Calloso-bruchus analis (Tabassum, et al., 1994). P. juliflora leaf extract was also effective on Plutella xyostella larvae (Torres et al., 2001). No reference was found on the effect of seeds except for our earlier work (Al-Moajel and Al-Dosary, 2002, 2003) on $C$. maculatus insect. Adults of $C$. maculatus were more susceptible than adults of $S$. oryzae. This is in agreement with Shaaya, et al. (1997). They found that out of four major stored-product insects, $S$. oryzae showed the highest tolerance to the oils tested.

Additionally, pet-ether extract has been found most toxic against C. maculatus (Al-Moajel and Al-Dosary, 2003), whereas in this study, chloroform extract was most toxic to $S$. oryzae.

EFFECT ON OVIPOSITION AND ADULT EMERGENCE BEHAVIOR: Table 3 compares the ovipoitional response of $S$. oryzae exposed to the extracts of $P$. juliflora seeds. The mean number of eggs laid in grain treated with mesquite extracts, both at lower and higher concentrations $\left(\mathrm{LC}_{50}\right.$ and $\mathrm{LC}_{95}$ ), was observed to be minimum (0.7-17 eggs). Maximum deterrence of oviposition was obtained from all extracts at $\mathrm{LC}_{95}$ concentrations (98-99\%), while $84-92 \%$ ovipositional reduction was observed at $\mathrm{LC}_{50}$ concentrations. When adults were fed with wheat grains treated with solvents only (controls: pet-ether, chloroform and acetone), the mean number of eggs laid was $76.4,94.7,106.7$ eggs per 10 pairs, respectively. It is apparent from the data presented in Table 3 that a significant oviposition deterency effect $(\mathrm{P}<0.05)$ was found for all extracts at $\mathrm{LC}_{50}$ concentrations, while at $\mathrm{LC}_{95}$ concentrations, oviposition was nearly completely inhibited.

A $97-85 \%$ reduction in progeny was observed at $\mathrm{LC}_{50}$ concentrations of pet- ether and chloroform extracts, respectively. T-test analysis showed that there were significant differences, while progeny emergence was completely suppressed in grains combining $\mathrm{LC}_{95}$ concentration of all extracts, and also at $\mathrm{LC}_{50}$ of acetone extract.

Complete reduction in progeny of $S$. oryzae reared on wheat grains treated with $\mathrm{LC}_{95}$ concentrations could be possible based upon the observed high adult mortality. At $\mathrm{LC}_{50}$ concentration of acetone extract, egg laying was reduced by $86 \%$, but progeny emergence was reduced by $100 \%$, thus acetone extract could be considered as an ovicide for S. oryzae. 


\section{TABLE 3}

Efficacy of different seed extracts of Prosopis juliflora against $\mathrm{S}$. oryzae for ovipositional and progeny deterent properties in wheat grain.

\begin{tabular}{|c|c|c|c|c|c|c|c|}
\hline Extract & $\begin{array}{c}\text { Concentration } \\
(\mathrm{ml} / \mathrm{kg})\end{array}$ & $\begin{array}{l}\text { Average no. of eggs } \\
\text { laid/10 pairs } \pm \mathrm{SE}\end{array}$ & $\mathrm{T}$-value & $\begin{array}{l}\text { Oviposition } \\
\text { reduction \% }\end{array}$ & $\begin{array}{l}\text { Average no. of } \\
\text { emergers } \pm \mathrm{SE}\end{array}$ & T-value & $\begin{array}{l}\text { Emergence } \\
\text { reduction \% }\end{array}$ \\
\hline $\begin{array}{l}\text { Pet-ether } \\
\text { Test of Significance }\end{array}$ & $\begin{array}{l}\text { Control } \\
\mathrm{LC}_{50}(4.1) \\
\mathrm{LC}_{95}(8.0)\end{array}$ & $\begin{array}{r}76.4 \pm 0.38 \\
5.2 \pm 0.61 \\
0.7 \pm 0.06\end{array}$ & $\begin{array}{c}-98.68 \\
-194.82 \\
S \\
\end{array}$ & $\begin{array}{l}92^{*} \\
99^{*}\end{array}$ & $\begin{aligned} 29.7 & \pm 1.2 \\
0.7 & \pm 0.12 \\
0.0 & \pm 0.00\end{aligned}$ & $\begin{array}{c}-24.19 \\
- \\
S\end{array}$ & $\begin{array}{c}97^{*} \\
100\end{array}$ \\
\hline $\begin{array}{l}\text { Chloroform } \\
\text { Test of Significance }\end{array}$ & $\begin{array}{l}\text { Control } \\
\mathrm{LC}_{50}(2.2) \\
\mathrm{LC}_{95}(6.3)\end{array}$ & $\begin{array}{r}94.7 \pm 2.40 \\
15.0 \pm 1.20 \\
1.7 \pm 0.00\end{array}$ & $\begin{array}{c}-29.79 \\
-28.54 \\
\mathrm{~S} \\
\end{array}$ & $\begin{array}{l}84^{*} \\
98^{*}\end{array}$ & $\begin{aligned} 25.7 & \pm 0.0 \\
3.7 & \pm 0.00 \\
0.0 & \pm 0.00\end{aligned}$ & $\begin{array}{c}-65.99 \\
- \\
S\end{array}$ & $\begin{array}{c}85^{*} \\
100\end{array}$ \\
\hline Test of Significance & $\begin{array}{l}\text { Control } \\
\operatorname{LC}_{50}(5.8) \\
\operatorname{LC}_{95}(12.0)\end{array}$ & $\begin{array}{r}106.7 \pm 3.50 \\
17.0 \pm 1.70 \\
0.7 \pm 0.15\end{array}$ & $\begin{array}{c}-22.79 \\
-29.97 \\
\mathrm{~S}\end{array}$ & $\begin{array}{l}86^{*} \\
99^{*}\end{array}$ & $\begin{array}{r}34.7 \pm 0.93 \\
0.0 \pm 0.00 \\
0.0 \pm 0.00\end{array}$ & $\begin{array}{l}- \\
\text { - } \\
\text { S }\end{array}$ & $\begin{array}{l}100 \\
100\end{array}$ \\
\hline
\end{tabular}

${ }^{*} \mathrm{~S}=$ Significant $(\alpha=0.05)$.

Plant extracts are known to significantly reduce progeny emergence of stored grain and pulse insects (Kelany et al., 1991; Seck, et al., 1993; Ho et al., 1994; Talukder and Howse, 1995; Huang, et al., 1997; Dwivedi and Kumar, 1998; Elhag, 2000; Papachristos and Stamopoulos, 2002).

Some workers have observed a reduction in oviposition of $S$. oryzae weevils on grains treated with plant extracts (Risha et al., 1990; Su, 1990, Schmidt et al., 1991; Mostafa et al., 1995, Mahgoub et al., 1998; Ahmed, 2000, 2002). These results were confirmed by Al-Moajel and Al-Dosary (2003), who reported that $P$. juliflora seed extracts were effective in reducing the oviposition and progeny emergence of $C$. maculatus.

RESIDUAL EFFECT: All the seed extracts at LC $\mathrm{L}_{95}$ concentrations gave almost complete protection until 15 days of storage (Table 4), but gradually the residual toxicities of pet-ether and acetone extracts decreased with length of storage. So, after 30 days of storage, the number of killed insects in the treated wheat grains was only 75 and $40 \%$ respectively, while in the grains treated with chloroform extracts $90 \%$ mortality of $S$. oryzae was recorded after this period of exposure. Consequently, adult mortality in chloroform extracts over various storage durations seem to have remained almost as the initial activity. The chloroform extract of $P$. juliflora seeds may give a higher degree of protection for stored wheat grains against $S$. oryzae, while the two other extracts were less effective. No mortality was recorded in solvent controls.

It should also be noted that effectiveness of $\mathrm{LT}_{95}$ concentrations of chloroform extract lasts longer than those of pet-ether and acetone. It can be concluded that chloroform extract indicated a slow rate of degradation after 1 month of storage.
Similar result on the effectiveness of plant extracts for nearly one month of storage were also obtained by Ahmed and Kassis, (2000) with Lupinus termis extracts against $C$. maculatus; Al-Moajel and Abd El-Baki, (2000) with Brassica rapa extracts against $R$. dominica; and Ahmed et al., (2002) with Capparis spinosa extracts against $C$. maculatus. On the other hand, some plant extracts were effective as adulticide over 2-8 months of storage: Kelany et al. (1991) and Mahgoub (1992) with neem extracts against $C$. chinensis and $C$. maculatus respectively; Mostafa et al. (1995) with Nigella sativa extracts against $S$. oryzae and Al-Moajel (2000) with Brassica napus against $S$. granarius. In respect of $P$. juliflora extracts, these results are in agreement with the findings of $\mathrm{Al}$ Moajel and Al-Dosary (2002) on cowpea seeds against $C$. maculatus.

\section{TABLE 4}

Susceptibility of S. oryzae adults to wheat grains treated with P. juliflora seed extracts after different intervals of storage.

\begin{tabular}{lcccc}
\hline \multirow{2}{*}{$\begin{array}{l}\text { Intervals of } \\
\text { storage (days) }\end{array}$} & Pet-ether & Chloroform & Acetone & Control \\
\cline { 2 - 5 } Initial & 100 & 98 & 98 & 0 \\
3 & 96 & 96 & 95 & 0 \\
6 & 96 & 95 & 96 & 0 \\
9 & 95 & 96 & 96 & 0 \\
12 & 94 & 94 & 94 & 0 \\
15 & 95 & 96 & 94 & 0 \\
18 & 93 & 95 & 90 & 0 \\
21 & 88 & 95 & 85 & 0 \\
24 & 85 & 95 & 60 & 2 \\
27 & 82 & 90 & 52 & 0 \\
30 & 75 & 90 & 40 & 0 \\
Slope & -3.73 & -1.86 & -2.21 & \\
LT $_{95}$ & 12 & 14 & 8 & \\
LT $_{50}$ & 33 & 104 & 43 & \\
\hline
\end{tabular}


TABLE 5

Effect of $P$. juliflora seed extracts on germination of wheat grains initially and 30 days after treatment (DAT).

\begin{tabular}{|c|c|c|c|c|}
\hline \multirow[b]{2}{*}{$\begin{array}{l}\text { Extract and } \\
\text { concentration } \\
(\mathrm{ml} / \mathrm{kg})\end{array}$} & \multicolumn{2}{|c|}{ Initially } & \multicolumn{2}{|c|}{30 days after treatment } \\
\hline & $\begin{array}{c}\% \\
\text { Germination } \\
\pm \mathrm{SEM}\end{array}$ & $\stackrel{\%}{\%}$ Reduction & $\begin{array}{c}\% \\
\text { Germination } \\
\pm \text { SEM }\end{array}$ & $\begin{array}{c}\% \\
\text { Reduction }\end{array}$ \\
\hline Control & $98+1.15^{\text {bod }}$ & & $96+1.00^{c d e}$ & \\
\hline Pet-ether (8.0) & $92+0.00^{x b}$ & 6.2 & $90+0.00^{\text {shi }}$ & 6.3 \\
\hline Chloroform (6.3) & $88+1.15^{\mathrm{c}}$ & 10.2 & $84+2.00^{a 4}$ & 12.5 \\
\hline Acctone $(12.0)$ & $84+2.31^{s d}$ & 14.2 & $81+0.58^{\mathrm{tc}}$ & 15.6 \\
\hline F-ratio & 17.82 & & 33.19 & \\
\hline F-tabulated & \multicolumn{4}{|c|}{4.07} \\
\hline LSD & 4.61 & & 3.79 & \\
\hline
\end{tabular}

Means within column followed by same letter are significantly different at $\mathrm{P}<0.05$.

EFFECT ON GRAIN VIABILITY: Data in Table (5) show that the germination of grains treated with pet-ether, chloroform and acetone extracts at the rates of 8.0,6.3, and $12.0 \mathrm{ml} / \mathrm{kg}$ respectively was significantly reduced initially or after storage time. All treatments gave $6.2-$ $15.6 \%$ reduction in germination. The lowest germination was in grains treated with acetone extract $(84-81 \%)$, at two intervals: initially and after 30 days of storage, respectively.

Our results are in agreement with Khaire et al. (1992), Pacheco et al. (1995) and Abdel-Latif (2003), who reported adverse effects of plant extract and oil treatments on germination of seeds and grains, significantly reducing percentage germination.

On the contrary, others found negligible effects of other plants on germination (Singh and Singh, 1990).

EFFECT ON WATER ABSORPTION: Table 6 shows that in initial studies (1 hour after application), chloroform and acetone treatments absorbed significantly more water than the control. Also 5 hours after application all three extract treatments absorbed significantly more water than the controls. Other treatments at initial time and all treatments after the storage period (30 days) recorded negligible (not significant) effects on the amount of water absorbed.

This effect has been reported in previous studies with other plants (Begum and Quiniones, 1990; Mahgoub et al. 1998; Shemais and Al-Moajel, 2000), found no effect on water absorption. Tembo and Murfitt (1995), however, reported significant effects of some plant oils on water absorption.

EFFECT ON WEIGHT LOSS: Table 7 indicated that the percentage losses in grain weight in different treatments ranged $1-5 \%$, while the percent weight loss was maximum in controls (11.33\%).

Chloroform extract at $\mathrm{LC}_{95}$ concentration was found to be the best one preventing the damage, recording only $1 \%$ loss. There were significant differences $(P<0.05)$ between the weight loss of treated wheat grains and controls after 2 months. The percentage
TABLE 6

Effect of P. juliflora seed extracts on water absorption of wheat grains initially and 30 days after treatment.

\begin{tabular}{|c|c|c|c|c|c|c|}
\hline \multirow{3}{*}{$\begin{array}{l}\text { Extract and } \\
\text { concentration } \\
(\mathrm{ml} / \mathrm{kg})\end{array}$} & \multicolumn{6}{|c|}{$\%$ Water absorption } \\
\hline & \multicolumn{3}{|c|}{ Initially } & \multicolumn{3}{|c|}{30 days after application } \\
\hline & $1 \mathrm{hr}$ & $5 \mathrm{hrs}$ & $24 \mathrm{hrs}$ & $1 \mathrm{hr}$ & $5 \mathrm{hrs}$ & $24 \mathrm{hrs}$ \\
\hline Control & $18^{b}$ & $32^{b}$ & $51^{a}$ & $14^{\mathrm{a}}$ & $28^{2}$ & $50^{2}$ \\
\hline Pet-ether (8.0) & $21^{\text {sb }}$ & $35^{4}$ & $52^{\mathrm{a}}$ & $17^{*}$ & $31^{2}$ & $50^{\circ}$ \\
\hline Chloroform (6.3) & $23^{2}$ & $38^{4}$ & $55^{a}$ & $14^{a}$ & $29^{\prime}$ & $50^{\mathrm{A}}$ \\
\hline Acetone $(12.0)$ & $23^{2}$ & $38^{\prime}$ & $56^{\mathrm{a}}$ & $14^{\mathrm{a}}$ & $27^{3}$ & $47^{2}$ \\
\hline F-ratio & 4.47 & 37.50 & 2.96 & 2.25 & 13.2 & 1.59 \\
\hline F-tabulated & \multicolumn{6}{|c|}{4.0661} \\
\hline
\end{tabular}

Means followed by the same letter are not significantly different at $P<0.05$, comparison made for columns.

losses in grain weight were significantly lower in grain treated with acetone extract $(\mathrm{t}=6.01-6.29)$ than in grain treated with both other extracts, and the percentage weight loss was significantly higher in wheat grains treated with chloroform extract $(\mathrm{t}=8.32-11.72)$ at $\mathrm{LC}_{50}$ and $\mathrm{LC}_{95}$ concentrations, respectively.

Consequently, chloroform extract at $\mathrm{LC}_{95}$ was most effective in reducing the grain weight loss which was $91 \%$. All plant extracts protect the grains against feeding by $S$, oryzae.

The effectiveness of some plant materials: powders, oils and extracts, on weight loss reduction have been reported in several studies on other insect species (Begum and Quiniones, 1990; Shivanna et al., 1994; Singh, 1995; Keita et al., 2001; Abdel-Latif, 2003) and on S. oryzae (Niber, 1994; Chimbe and Galley, 1996).

EFFect on Esterase And Phosphatase EnZymes: Table 8 indicates the acetylcholinesterase (AchE) and phosphatases (AcP and AlkP) enzyme activity of $S$, oryzae adults treated with $\mathrm{LC}_{50}$ of $P$. julifora seed extracts after 72 hours of exposure. The data revealed that in the pet-ether and chloroform extract treatments, AchE enzyme decreased significantly (1101.48 and 1057.67

\section{TABLE 7}

Grain weight losses caused by S. oryzae weevils infesting stored wheat grains treated with $\mathrm{P}$. juliflora seed extracts.

\begin{tabular}{|c|c|c|c|c|}
\hline Extract & $\begin{array}{l}\text { Concentra- } \\
\text { tion }(\mathrm{ml} / \mathrm{kg})\end{array}$ & $\begin{array}{c}\% \text { Loss in } \\
\text { weight } \pm \text { SE }\end{array}$ & $\mathrm{T}$-value & $\begin{array}{c}\% \\
\text { Protection } \\
\end{array}$ \\
\hline \multirow{3}{*}{ Pre-ether } & Control & $11.33 \pm 0.88$ & & \\
\hline & $\mathrm{LC}_{50}(4.1)$ & $3 \pm 0.58$ & 7.91 & 75 \\
\hline & $\mathrm{LC}_{95}(8.0)$ & $2 \pm 0.00$ & 10.58 & 83 \\
\hline \multicolumn{2}{|c|}{ Test of significance } & S & & \\
\hline \multirow{3}{*}{ Chloroform } & Control & $11.33 \pm 0.88$ & & \\
\hline & $\mathrm{LC}_{50}(2.2)$ & $4 \pm 0.00$ & 8.32 & 66 \\
\hline & $\mathrm{LCog}(6.3)$ & $1 \pm 0.00$ & 11.72 & 91 \\
\hline \multicolumn{2}{|c|}{ Test of significance } & $\mathrm{S}$ & & \\
\hline \multirow{3}{*}{ Acetone } & Control & $11.33 \pm 0.88$ & & \\
\hline & $\mathrm{LC}_{50}(5.8)$ & $5 \pm 0.58$ & 6.01 & 58 \\
\hline & $\mathrm{LC}_{95}(12.0)$ & $4 \pm 0.76$ & 6.29 & 66 \\
\hline \multicolumn{2}{|c|}{ Test of significance } & $S$ & & \\
\hline
\end{tabular}

$* \mathrm{~S}=$ Significant $(\alpha=0.05)$. 
TABLE 8

Effect of $\mathrm{P}$. juliflora seed extracts $\left(L C_{95}\right)$ on the rate of acetylcholinesterase (AchE) and Phosphatases (AcP and AlkP) in $\mathrm{S}$. oryzae 72 hrs after treatment.

\begin{tabular}{|c|c|c|c|c|c|c|c|c|c|c|c|c|}
\hline \multirow{3}{*}{$\begin{array}{l}\text { Extract and } \\
\text { concentration } \\
(\mathrm{m} / \mathrm{kg})\end{array}$} & \multicolumn{4}{|c|}{$\operatorname{AchE}(\mu \mathrm{g} / \mathrm{g} / \mathrm{min})$} & \multicolumn{4}{|c|}{$\mathrm{AcP}(\mu \mathrm{g} / \mathrm{g} / \mathrm{min})$} & \multicolumn{4}{|c|}{ AlkP ( $\mu \mathrm{g} / \mathrm{g} / \mathrm{min})$} \\
\hline & \multirow{2}{*}{ Mean \pm SE } & \multicolumn{3}{|c|}{$95 \%$ Confidence interval } & \multirow{2}{*}{ Mean \pm SE } & \multicolumn{3}{|c|}{$95 \%$ Confidence interval } & \multirow{2}{*}{ Mean $\pm \mathrm{SE}$} & \multicolumn{3}{|c|}{$95 \%$ Confidence interval } \\
\hline & & Lower & Upper & T-value & & Lower & Upper & T-value & & Lower & Upper & T-value \\
\hline Control & $1222.07 \pm 16.15$ & 1190.89 & 1244.92 & & $281.39 \pm 4.97$ & 179.11 & 292.74 & & $4.63 \pm 0.16$ & 4.31 & 4.85 & \\
\hline \multirow{2}{*}{$\begin{array}{l}\text { Pre-ether (4.1) } \\
\text { Test of } \\
\text { significance }\end{array}$} & $1101.48 \pm 42.82$ & 1027.39 & 1175.73 & 23.39 & $311.63 \pm 5.55$ & 303.48 & 322.23 & 38.14 & $6.33 \pm 0.23$ & 6.08 & 6.79 & -404.06 \\
\hline & & S & & & & s & & & & s & & \\
\hline \multirow{2}{*}{$\begin{array}{l}\text { Chloroform (2.2) } \\
\text { Test of } \\
\text { significance }\end{array}$} & $1057.67 \pm 68.39$ & 950.34 & 1184.77 & 14.00 & $233.65 \pm 8.29$ & 221.34 & 249.43 & 16.12 & $5.41 \pm 0.31$ & 4.92 & 5.97 & -310.01 \\
\hline & & S & & & & S & & & & S & & \\
\hline \multirow{2}{*}{$\begin{array}{l}\text { Acetone (5.8) } \\
\text { Test of } \\
\text { significance }\end{array}$} & $1230.41 \pm 26.89$ & 1199.89 & 1284.01 & 42.05 & $253.85 \pm 4.19$ & 247.17 & 261.56 & 36.76 & $10.95 \pm 0.39$ & 10.19 & 11.47 & -228.59 \\
\hline & & s & & & & S & & & & $\mathrm{S}$ & & \\
\hline
\end{tabular}

$\mathrm{S}=$ significant $(\alpha=0.05)$.

$\mu \mathrm{m} / \mathrm{g} / \mathrm{min}$ for the two extracts, respectively) compared with 1222.07 in the control. But in case of acetone extract, AchE activity increased slightly (1230.41 $\mu \mathrm{m} / \mathrm{g} / \mathrm{min})$.

AcP activity was significantly inhibited by the use of chloroform and acetone extracts (233.65 and 253.85 $\mu \mathrm{m} / \mathrm{g} / \mathrm{min}$ respectively) compared with 281.39 in the control, while at pet-ether extract AcP was significantly increased (311.63).

On the other hand, AlkP activity increased at all tested extracts, reaching $6.33,5.41$ and $10.95 \mu \mathrm{m} / \mathrm{g} / \mathrm{min}$ with pet-ether, chloroform and acetone extracts treatments, respectively. Acetone extract caused the greatest effect.

So pet-ether and chloroform extracts caused a significant inhibition of AchE, and similar effects on AcP.

On the contrary, all treatments caused a significant activation of AlkP. AcP was activated in the pet-ether treatment. Ahmed (2000) found that after 72 hours of exposure, Ricinus communis seed extracts had caused an inhibition effect in $S$. oryzae adults.

EFFECT ON METABolites: Data presented in Table 9 shows that after 72 hours of $P$. juliflora seed extract treatments, the total protein content significantly decreased at all extracts. Protein content was the lowest $(13.78 \mathrm{mg} / \mathrm{g})$ in adults treated with chloroform extract, and similar in pet-ether and acetone extracts (16.59 and 16.48 , respectively) compared with $20.08 \mathrm{mg} / \mathrm{g}$ in the control treatment.

On the contrary, total lipids were significantly increased by all extracts. Total lipids were the highest (36.95 $\mathrm{mg} / \mathrm{g}$ ) in the chloroform extract treatment, whereas at pet-ether and acetone extracts treatments, total lipids had a significant normal increase (a mean of 22.25 and $21.58 \mathrm{mg} / \mathrm{g}$ respectively) compared with $20.02 \mathrm{mg} / \mathrm{g}$ in the control. Meanwhile, the carbohydrate content was significantly higher in adults treated with

TABLE 9

Effect of $\mathrm{P}$. juliflora seed extracts $\left(L C_{50}\right)$ on the rate of main metabolites in $\mathrm{S}$. oryzae 72 hrs after treatment.

\begin{tabular}{|c|c|c|c|c|c|c|c|c|c|c|c|c|}
\hline \multirow{3}{*}{$\begin{array}{l}\text { Extract and } \\
\text { concentration } \\
(\mathrm{m} / \mathrm{kg})\end{array}$} & \multicolumn{4}{|c|}{ Total proteins (mg/g) } & \multicolumn{4}{|c|}{ Total lipids (mg/g) } & \multicolumn{4}{|c|}{ Total cartohydrates (mg/g) } \\
\hline & \multirow{2}{*}{ Mean \pm SE } & \multicolumn{3}{|c|}{$95 \%$ Confidence interval } & \multirow{2}{*}{ Mean \pm SE } & \multicolumn{3}{|c|}{$95 \%$ Confidence interval } & \multirow{2}{*}{ Mean $\pm \mathrm{SE}$} & \multicolumn{3}{|c|}{$95 \%$ Confidence interval } \\
\hline & & Lower & Upper & T-value & & Lower & Upper & T-value & & Lower & Upper & T-value \\
\hline Control & $20.08 \pm 0.67$ & 18.85 & 21.17 & & $20.02 \pm 0.97$ & 18.30 & 21.65 & & $14.17 \pm 0.43$ & 13.41 & 14.91 & \\
\hline Pre-ether (4.1) & $16.59 \pm 0.60$ & 15.89 & 17.79 & -138.07 & $22.25 \pm 0.47$ & 21.47 & 23.09 & -165.91 & $6.20 \pm 0.21$ & 5.8 & 6.50 & $-404,06$ \\
\hline $\begin{array}{l}\text { Test of } \\
\text { significance }\end{array}$ & & $\mathrm{S}$ & & & & $\mathrm{S}$ & & & & $\mathrm{S}$ & & \\
\hline Chloroform (2.2) & $13.78 \pm 0.24$ & 13.32 & 14.12 & -362.60 & $36.95=1.39$ & 34.32 & 39.03 & -45.43 & $11.24 \pm 0.50$ & 10.34 & 12.08 & -176.47 \\
\hline $\begin{array}{l}\text { Test of } \\
\text { significance }\end{array}$ & & $\mathrm{S}$ & & & & $\mathrm{S}$ & & & & $\mathrm{S}$ & & . \\
\hline Acetone (5.8) & $16.48 \pm 0.14$ & 16.21 & 16.69 & -589.11 & $21.58 \pm 1.34$ & 19.39 & 23.16 & -69.15 & $15.08 \pm 0.44$ & 14.37 & 15.87 & -195.41 \\
\hline $\begin{array}{l}\text { Test of } \\
\text { significance }\end{array}$ & & $\mathrm{S}$ & & & & $\mathrm{S}$ & & & & $\mathrm{S}$ & & \\
\hline
\end{tabular}

$\mathrm{S}=$ significant $(\alpha=0.05)$. 
acetone extracts $(15.08 \mathrm{mg} / \mathrm{g})$, and significantly lower (6.20 and $11.24 \mathrm{mg} / \mathrm{g}$ ) under pet-ether and chloroform extracts respectively, compared with $14.17 \mathrm{mg} / \mathrm{g}$ in the control.

All extracts caused a significant decrease in protein and carbohydrate contents of adults, except the carbohydrate content of adults treated with acetone extract; meanwhile there was a significant increase of lipid and carbohydrate contents in adults treated with all extracts.

The results showed that the lowest amount of protein and the highest amount of lipid was in the chloroform extract treatments, and the lowest amount of carbohydrate was in pet-ether extract treatment. Reduction in protein and carbohydrate contents and increase of lipid content with $P$. juliflora seed extracts may be due to its prevention action. These results of increasing lipid are in agreement with Mostafa and Sherif (1993) who used different plant powders.

\section{Conclusions}

To the best of our knowledge, no study has been reported previously concerning the activity of seeds of $P$. juliflora as protectant. Seeds of $P$. juliflora plant are useful grain protectant. These results indicate that in addition to its toxic effect on $S$. oryzae adults, the fecundity of adults and weight loss of wheat grains were reduced. Chloroform extract was the most effective on adult mortality with more active of residual effects and less gram weight loss than the other tested extracts. Further research into the constituents and bioactivity of $P$. juliflora seed extracts is needed.

\section{Acknowledgements}

I am a grateful to Mrs. A. Al-Raddady for guidance on statistical analysis.

\section{References}

Abbott, W.S. 1987. A method of computing the effectiveness of an insecticide. Journal of the American Mosquito Control Association 3:302-303.

Abdel-Latif, A.M. 2003. Effect of some plant oils as protectants of stored legumes against cowpea beetle, Collosobruchus masculatus (F.) infestation. Fayoum Journal of Agricultural Research and Development 17:98-106.

Ahmed, A., V. Ahmed, S.M. Khalid, F.A. Ansari and K.A. Khan. 1997. Studyon the antifungal efficacy of juliflorine and benzeneinsoluble alkaloidal fraction of Prosopis juliflora. Philippine Journal of Science 126:175-182.

Ahmed, S.M.S. 2000. Laboratory evaluation of some biological activity of Ricinus communis seed extracts against the rice weevil, Sitophilus oryzae (L.). Arab Universities Journal of Agricultural Sciences, Ain Shams University, Cairo, 8:853-861.

Ahmed, S.M.S. 2002. Evaluation of wild mint Mentha longifolia and clove Eugenia aromatica powders for the control of Callosorbruchus maculatus (F,) and Sitophilus oryzae (L.). Fayoum Journal of Agricultural Research and Development 16:30-39.

Ahmed, S.M.S. and S.R. Kassis. 2000. Efficiency of lupin seeds Lapinus termis extracts against cowpea beetle Callosobruchus maculatus (F.) and granary weevil Sitophilus granaries (L.). Fayoum Journal of Agricultural Research and Development 14:7-17.

Ahmed, S.M.S., S.M. Mahgoub and S.M. Orsy, 2002. Caper extract as protectant of cowpea seeds against the cowpea beetle, Callosobruchus maculatus (F.) and the impact of treatment on seed technology. Fayoum Journal of Agricultural Research and Development 16:90-98.

Al-Moajel, N.H. 2000. Tumip seed (Brassica napus) extracts as grain wheat protectants against the granary weevil, Sitophilus granaries L. Saudi Journal of Biological Sciences 7:94-103.

Al-Moajel, N.H. 2003. Effect of coriander and cardamon seed extracts on mortality reproduction of the cowpea beetle, Callosobruchus maculatus Fab. Fayoum Journal of Agricultural Research and Development 17:1-10.

Al-Moajel, N.H. and S.M. Abd El Baki. 2000. Brassica rapa (Rape) seed extracts as protectants to wheat grains against the lesser grain borer Rhizopertha dominica (F.) Annals of Agricultural Sciences, Ain Shams University, Cairo 45:353-362.

Al-Moajel, N.H. and M.M. Al-Dosary. 2002. Mesquite plant, Prosopos juliflora (SW). D.C. powders as protectants of mung bean, vigna unguidulata L. Walp. against Callosobruchus maculatus (Fab.) infestation. Journal of the Egyptian-German Society of Zoology 39(E):Entomology, 67-77.

Al-Moajel, N.H. and M.M. Al-Dosary. 2003. Efficacy of mesquite, Prosopis juliflora (SW). D.c. powders as protectants of mung bean, Vigna unguiculata L. Walp. against Callosobruchus maculates Fab. Fayoum Journal of Agricultural Research and Development 17:11-19.

Anonymous. 1966. International rules for seed testing. Proceedings of International Testing Association XXXI 31:49-91.

Arroyo, M. 1995. Lucha contra las plagas y protecc de los cultivos: una a proxim acton historica. In: Conferencias del Seminario de Fitopatologia, C. Aya, C. Dolores, L. Bethencourt and R.M. Cabrera (Editors), 41-51. Departamento Biologia Vegetal Universidad de La Laguna, Spain.

Begum, S. and A.C. Quiniones. 1990. Protection of stored mungbean seeds from bean weevil Callosobruchus chinensis by vegetable oil application. Bangladesh Journal of Zoology 18:203-210.

Bradford, M.M. 1976. A rapid and sensitive method for the quantitation of microgram quantities of protein utilizing the principle of protein-dye binding. Annals of Biochemistry 77:248254.

Chander, H., S.G. Kulkami and S.K. Berry. 1991. Effectiveness of turmeric powder and mustard oil as protectants in stored milled rice against the rice weevil, Sitophilus oryzae. International Pest Control 4:94-97.

Chaudhary, S.A. and A.A. Al-Jowaid. 1999. Vegetation of the Kingdom of Saudi Arabia. National Agriculture and Water Research Center, Ministry of Agriculture and Water, Riyadh, Saudi Arabia.

Chimbe, C.M. and D.J. Galley. 1996. Evaluation of material from plants of medicinal importance in Malawi as protectants of stored grain against insects. Crop Protection 15:289-294.

Collenette, S. 1998. A Checklist of Botanical Species in Saudi Arabia. International Asclepiad Society Headlcy Ltd., Ashford, Kent, U,K.

Collenette, S. 1999. Wild Flowers of Saudi Arabia. National Commission for Wildlife Conservation and Development (NCWCD), Riyadh, Saudi Arabia.

Duncan, D.B. 1951. A significance test for differences between ranked treatments in an analysis of variance. Virginia Journal of Sciences 2:171-189.

Dwivedi, S.C. and R. Kumar. 1998. Evaluation of Cassia occidentalis leaf extracts on development and damage caused by Trogoderma granarium, khapra beetle. Journal of Eco-tourism Environmental Monitor 8:55-58.

Elhag, E.A. 2000. Deterrent effects of some botanical products on oviposition of cowpea bruchid Callosobruchus maculatus (F.) (Coleoptera: Bruchidae). International Journal of Pest Management 46:109-113.

El-Lakwah, F.A., A.M. Abdel-latif and Z.A. Halawa. 1998. Effect of Conyza dioscoridis leaf extracts on three major insects of stored 
products in Egypt. Egypt Journal of Agricultural Research 75:971-982.

Frankenfeld, J.C. 1950. Staining Method of Detecting Hidden weevil Infestation in Grains. US Patent No, 2:25-898.

Gomathi, V. and B. Kannabiran. 2000. Inhibitory effects of leaf extract of some plants on the anthracnose fungi infecting Capsicum annum. Indian Phytopathology 53:305-308.

Halstead, D.G.M. 1963. External sex differences in stored products Colcoptera. Bulletin of Entomological Research 54:119-134.

Ho, S.H., L.P.L. Cheng, K.Y. Sim and H.T.W. Tan. 1994. Potential of cloves, Syzygium aromaticum (L.) Merr and Perry as a grain protectant against Tribolium castaneum (Herbst) and Sitophilus zeamais Motsch. Postharvest Biological Technology 4:179-183.

Huang, Y., J.M.W.L. Tan, R.M. Kini and S.H. Ho, 1997. Toxic and antifeedant action of nutmeg oil against Tribolium castanetum (Herbst) and Sitophilus zeamais Motsch. Joumal of Stored Products Research 33:289-298.

Islam, B.N. 1983. Pesticidal action on neem and certain indigenous plants. Proceedings of the $2^{\text {nd }}$ International Neem Conference, $\mathrm{p}$. 263-290, Rauischholzhausen.

Jahan, M., I. Ahmed and S.N.H. Naqui. 1990. Toxic and tertaogenic effects of juliflorine and Margasan. $\mathrm{O}^{\mathrm{TM}}$ on the Musca domestica L. larvae. Proceedings of Pakistan Congress of Zoology 10:293299.

Keita, S.M., Ch. Vincent, J.P. Schmit, J.T. Arnason and A. Belanger. 2001. Efficacy of essential oil of Ocimum basilicum L. and $O$ gratissimum $\mathrm{L}$. applied as an insecticidal fumigant and powder to control Callosobruchus maculatus (Fab.) (Coleoptera: Bruchidae). Journal of Stored Products Research 37:339-349.

Kelany, I.M., Sh.M. Omara and A.M. Zeinab. 1991. Biological changes of cowpea weevil, Callosobruchus chinensis (Linn.) as influenced by plant extracts of neem seed kernels. Minia Journal of Agricultural Research 13:757-778.

Kestenholz, C. and C. Stevenson. 1998. Gardenia spp. as a source of botanical pesticide against the rice weevil, Sitophilus oryzae L. (Coleoptera, Curculionidac) in Sri Lanka. The Brighton Conference. Pests and Diseases. 6D 1:543-548.

Khaire, V.M., B.V. Khaire and U.N. Mote. 1992. Efficacy of different vegetable oils as grain protectants against pulse beetle, Callosobruchus chinensis (L.) in increasing storability of pigeon pea. Journal of Stored Products Research 28:153-156.

Khare, B.P. and R.K. Johari. 1984. Influence of phenotypic characters of chickpea (Cicer arietinum L.) cultivars on their susceptibility to Callosobruchus chinensis (L.). Legume Research 7:54-56.

Knight, J.A., S. Anderson and J.M. Rawle. 1972. Chemical basis of the sulfophosphovanillin reaction for estimating serum lipids. Clinical Chemistry 18:199-202.

Kurucheve, V., J.G. Ezhilan and J. Jayaraj. 1997. Screening of higher plants for fungitoxicity against Rhizoctonia solani in vitro. Indian Phytopathlogy 50:235-241.

Mahgoub, S.M. 1992. Neem sced extracts and powders as grain protectants to cowpea seeds against the cowpea weevil, Callosobruchus maculatus Fab. Egyptian Joumal of Agricultural Research 70:487-497.

Mahgoub, S.M., S.M. Ahmed and S.M. Abel-Baki. 1998, Use of Petroselinum sativum oil for the protection of wheat grain and mung bean seeds against the rice weevil, Sitophilus oryzae L. and the cowpea beetle, Callosobruchus mactulatus (F.). Egyptian Journal of Agricultural Research 76:117-125.

Mostafa, T.S. and R.K. Sherif. 1993. Behavioral responses of some biochemical changes of the kapra beetle to some plant powders. Journal of the Egyptian-German Society of Zoology 12(D):335349 .

Mostafa, T.S., SM.S. Ahmed and S.M. Mahgoub. 1995. Evaluation of Nigella sativa seed extract for the control of Callosobruchus maculatus (F.) and Sitophilus oryzae (L.). Egyptian Journal of Applied Sciences 10:7-21.

Naqvi, S.N.H. and F. Parveen. 1991. Toxicity and residual effect of Nerium indicum crude extract as compared with Coopex against adults of Tribolium castaneum (Coleoptera: Tenebrionidae). Pakistan Journal of Entomological Science in Karachi 6:35-44.
Niber, B.T. 1994. The ability of powders and slurries from ten plant species to protect stored grain from attack by Prostephamus truncates Horn (Coleoptera:Bostrichidae) and Sitophilus oryzae L. (Coleoptera: Curculionidae). Journal of Stored Products Research 30:297-301.

Niber, B.T., J. Helenius and A.L. Varis. 1992. Toxicity of plant extracts to three storage beetles (Coleoptera). Journal of Applied Entomology 113:202-208.

Owusu, E.O. 2001. Effect of some Ghananian plant components on control of two stored-product insect of cereals. Journal of Stored Products Research 37:85-91.

Pacheco, I.A., M.F.P.P.M. de Castro, D.C. de Paula, A.L. Lourencao, S. bolonhezi, M.K. Barbieri. 1995. Efficacy of soybean and castor oils in the control of Callosobruchus maculatus (F.) and Callosobruchus phaseoli (Gyllchnahl) in stored chick-peas (cicer arietimum L.). Journal of Stored Products Research 31:221-228.

Papachristos, D.P. and D.C. Stamopoulos. 2002. Repellent, toxic and reproduction inhibitory effects of essential oil vapors on Acanthoscelides obtectus (Say) (Coleoptera: Bruchidae). Journal of Stored Products Research 38:117-128.

Powell, M.E.A. and M.J.H. Smith. 1954. The determination of serum acid and alkaline phosphatases activity with 4-amino antipyrine. Journal of Clinical Pathology 7:245-248.

Qi, Y.T. and W.E. Burkholder. 1981. Protection of stored wheat from the granary weevil by vegetable oils. Journal of Economic Entomology 74:502-505.

Risha, E.M., A.K.M. El-Nahal and G.H. Schmidt. 1990. Toxicity of vapours of Acones calamus L. oil to the immature stages of some storod-product Coleoptera. Journal of Stored Products Research 26:133-137.

Satish, S., K.A. Raveesha and G.R. Janardhana. 1999. Antibacterial activity of plant extracts on phytopathogenic Xanthomonas campestris pathorars. Letters in Applied Microbiology 28:145147.

Schmidt, G.H., E.M. Risha and A.K.M. El-Nahal. 1991. Reduction of progeny of some stored-product Coleptera by vapours of Aconts calamus oil. Journal of Stored Products Research 27:121-127.

Seck, D., G. Logany, E. Haubruge, J.P. Wathelet, M. Marlicr, C. Gaspar and M. Severin. 1993. Biological activity of the shrub Boscia senegalensis (Pers.) and Lam. Ex Poir. (Capparaceae) on stored grain insects. Journal of Chemical Ecology 19:377-389.

Shaaya, E., M. Kostjukovski, J. Eilberg and C. Sukprakarn. 1997. Plant oils as fumigants and contact insecticides for the control of stored-product insects, Journal of Stored Products Research 33:7-15.

Shaaya, E., V. Ravid, N. Paster, B. Juven, V. Zisman and V. Pissarev. 1991. Fumigant toxicity of essential oils against four majored stored-product insects. Journal of Chemical Ecology 17:499-504.

Shemais, S.A. and N.H. Al-Moajel. 2000. Efficiency and persistence of extracted capparis, Capparis spinosa seeds against the rice weevil, Sitophilus oryzae L. (Curculionidae: Coleoptera). Egyptian Journal of Applied Sciences 15:267-274.

Shivanna, S., S. Lingappa and B.V. Patil. 1994. Effectiveness of selected plant materials as protectants against pulse beetle, Callosorbuchus chinensis (Linn.) during storage of redgram. Karnataka Journal of Agricultural Sciences 7:285-290.

Sighamony, S., I. Anees, T. Chandrakala and Z. Osmani. 1986. Efficacy of certain indigenous plant products as grain protectants against Stiphilus oryzae (L.) and Rhyzopertha dominica (F.). Journal of Stored Products Research 22:21-23.

Simpson, D.R., D.L. Bull and D.D. Lindquist. 1964. A semimicro technique for the estimation of cholinesterase activity inn boll weevil. Annals of the Entomological Society of America $57: 367-377$.

Singh, S.K. 1995, Testing some vegetable oils for protection of gram seed during storage against Callosobruchus chinensis (L.). Journal of Insect Science 8:215-216.

Singh, S.K. and Z. Singh. 1990. Studies of plant oils as surface protectant against pulse beetle, Callosobruchus chinensis (L.) in chickpea, cicer arietinum L. in India. Tropical Pest Management 36:314-316. 


\section{AL-MOAJEL}

Singh, N.B. and R.N. Sinha. 1977. Carbohydrates, lipids and protein in the development stages of Sitophilus oryzae and Sitophilus granaries. Annals of the Entomological Society of America 107-111.

SPSS. 1999. SPSS 9 for Windows User's Guide. SPSS Inc. Chicago, IL.

Su, H.C.F. 1985. Laboratory study on effect of Anethum graveolens seeds on four species of stored-product insects. Journal of Economic Entomology 78:451-453.

Su., H.C.F. 1990. Biological activities of hexane extract of Piper cubeba against rice weevils and cowpea weevils (Coleoptera: Curculionidae). Journal of Entomological Sciences 25:16-20.

Tabassum, R., S.N.H. Naqvi, V.U. Ahmed, Sh. Rani, M. Jahan and M.A. Azmi. 1994. Toxicity determination of different plant extracts (Saponin and Juliflorine) and neem based pesticide Morgosan- $\mathrm{O}^{\mathrm{TM}}$ against stored grain pest Callosobruchus analis. Proceedings of Pakistan Congress of Zoology 14:326-333.

Talukder, F.A. and P.E. Howse. 1995. Evaluation of Aphanamixis polystachya as a source of repellents, antifeedants, toxicants and protectants in storage against Tribolitum castaneum (Herbst). Journal of Stored Products Research 31:55-61.
Tembo, E. and R.F.A. Murfitt. 1995. Effect of combining vegetable oil with Pirimiphos-methyl for protection of stored wheat against Sitophilus granaries (L.). Journal of Stored Products Research 31:77-81.

Tikka, K., O. Koul and B.P. Szxena. 1981. Possible mode of action of vegetable oils to protect Phaseolus aureus ROXB from bruchid attack. Science and Culture 47:103-105.

Torres, A.L., R. Barros and J.V. de Oliveire. 2001. Effects of plant aqueous extracts on the development of Plutella xyostella (L.) (Lepidoptera:Plutellidae). Neotropical Entomology 30:151-156.

White, N.D.G. 1995. Insect, mites and insecticides in stored grain ecosystem. In: Stored Grain Ecosystem, D.S. Jayus, N.D.G. White and W.E. Munir (Editors), pp 123-168. Marc and Dekker, New York.

Zettler, J.L. and G.W. Cuperus. 1990. Pesticide resistance in Tribolium castaneum (Coleoptera:Tenebionidae) and Rhyzopertha dominica (Coleoptera:Bostrichidae) in wheat. Journal of Economic Entomology 83:1677-1681.

Received April 2004.

Accepted September 2004 